\title{
Metabolic $\mathrm{CO}_{2}$ production in the Mediterranean Sea: A case study for estimating carbon budget in the sea*
}

\author{
ROSABRUNA LA FERLA and MAURIZIO AZZARO \\ IAMC - Istituto Sperimentale Talassografico (CNR), Spianata S. Raineri, 86, 98122 Messina, Italy. \\ E-mail: laferla@ist.me.cnr.it
}

\begin{abstract}
SUMMARY: A synthesis of published metabolic $\mathrm{CO}_{2}$ production rates determined in the water column of the Eastern Mediterranean Sea from 1993 to 1999 is reported with the aim of furnishing an overall picture of the remineralization processes occurring in the basin. The trends of the remineralization are also interpreted with respect to the so-called Eastern Mediterranean Transient (EMT) event. This study augments the sparse data set of respiration measurements, from oceanographic surveys, and highlights the tight coupling between biological processes and circulation patterns. In the photic zone, the rates decreased from West to East as well as from North to South. In the aphotic zone, the C remineralization trend followed the traditional routes of intermediate and deep waters in the Eastern Mediterranean Basin, and underwent the important modifications into the depths as a consequence of the EMT impact.
\end{abstract}

Keywords: ETS, metabolic production, remineralization, Mediterranean Sea, EMT

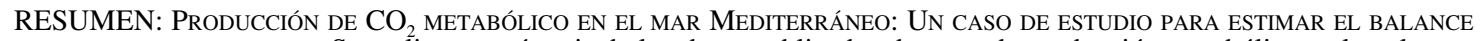
DE CARBONO EN EL MAR. - Se realiza una síntesis de los datos publicados de tasas de producción metabólica en la columna de agua en el mar Mediterráneo Oriental desde 1993 a 1999, con el fin de proporcionar una imagen general de los procesos de remineralización que tienen lugar en la cuenca. Las tendencias de la remineralización se interpretan asimismo en relación con el llamado evento Transitorio del Mediterráneo Oriental (EMT). Este estudio aumenta los escasos conjuntos de datos de mediciones de respiración procedentes de campañas oceanográficas y destaca el estrecho acoplamiento entre procesos biológicos y pautas de circulación. En la zona fótica, las tasas decrecen de oeste a este así como de norte a sur. En la zona afótica, la tendencia de la remineralización de $\mathrm{C}$ siguió las rutas tradicionales de aguas intermedias y profundas en la cuenca oriental del Mediterráneo, y experimentó las importantes modificaciones en aguas profundas como consecuencia del impacto del EMT.

Palabras clave: ETS, producción metabólica de $\mathrm{CO}_{2}$, remineralización, mar Mediterráneo, EMT.

\section{INTRODUCTION}

The biological pump controls the export of biogenic carbon from surface toward deeper layers in oceanic ecosystems. In simplified terms, the biological pump mechanism transforms the $\mathrm{CO}_{2}$ into organic matter in the euphotic zone by means of

*Received September 19, 2001. Accepted january 8, 2003. photosynthesis; the particulate fraction of this organic matter then sinks into the deeper waters where it can be remineralized to $\mathrm{CO}_{2}$ or sequestered in the sediments (Longhurst and Harrison, 1989; Sundquist, 1985). The production, vertical flux and remineralization are theoretically balanced among themselves, so that the determination of any one of these rates facilitates the estimation of the others (Eppley and Peterson, 1979). 
Current knowledge of primary production is exhaustive when compared to that on the sinking and degradation of organic matter in the sea. In fact, only in the last twenty years have oceanographers turned towards the sinking and oxidation of organic matter. Moreover, information obtained from sediment-trap studies has not proved conclusive (Sundquist, 1985) because these studies take into account only particulate matter but neglect dissolved matter. Organic matter oxidation studies represent an additional neglected part of oceanographic knowledge. Since the oxygen consumption rates in the oligotrophic and deep waters are often below detection limits of the analytical methods traditionally used, assessment of these rates requires high resolution, in terms of analytical sensitivity. The assay of respiratory electron transfer activity provides this sensitivity. This activity is the biochemical basis of real respiration and can be determined at low biomass where direct measurements of respiration are currently impossible (Packard, 1971; Packard and Williams, 1981). Furthermore, it can be used to evaluate the oxidation of organic carbon in both dissolved and particulate phases and therefore provides an overall picture of the remineralization processes (Packard et al., 1988; Christensen et al., 1989).

Our research focused on determining metabolic $\mathrm{CO}_{2}$ production in the Mediterranean Sea, a semienclosed basin where several ocean dynamic processes (i.e. intermediate and deep water formations, upwelling and so on) take place. Due to the small size of the Mediterranean, the relatively large role of lateral transport of organic matter from its shelf, and the brief residence time of its deep waters (Hopkins, 1978), this sea is an ideal basin for a mesoscale study of oceanic processes. During the study period, a transitory change in circulation occurred in the Eastern Mediterranean (Lascaratos et al., 1999), the so-called Eastern Mediterranean Transient (EMT) event (Roether et al., 1996; Klein et al., 2000). The EMT event has replaced the East- ern Mediterranean Deep Waters (EMDW) with younger waters of Aegean origin. This event produced a strong ecological impact on the deep biota of all the Eastern Mediterranean (Theocharis and Lascaratos, 2000), with an increasing level in productivity and nutrient concentration documented by Souvemerouglou et al. (1999), Psarra et al. (2000) and Tselepides et al. (2000).

In this paper, we report metabolic $\mathrm{CO}_{2}$ production rates from different oceanographic surveys carried out in the Eastern Mediterranean Sea from 1993 to 1999. A general picture of the Mediterranean remineralization rates in the photic and aphotic zone is drawn from these data and related to the main Mediterranean water masses and $\mathrm{CO}_{2}$ production rate estimates from the oceans.

\section{MATERIALS AND METHODS}

References of the multidisciplinary cruises with details on the sampling protocols are shown in Table 1. For analysis of respiratory electron transfer system (ETS) activity, the water samples were prefiltered through a $250 \mu \mathrm{m}$ mesh net to remove large particles and were concentrated on GF/F Whatman glass fiber membrane filters at reduced pressure $(<1 / 3 \mathrm{~atm})$. The filters were immediately stored in liquid nitrogen until analysis $(<45$ days) to prevent enzymatic decay (Ahmed et al., 1976).

The ETS assay was performed according to the tetrazolium reduction technique extensively described elsewhere (Packard, 1971) as modified by Kenner and Ahmed (1975) for microplankton communities. The ETS measurements were corrected for in situ temperature using an Arrhenius activation energy of $15.8 \mathrm{Kcal} \mathrm{mole}^{-1}$ (Packard et al., 1975). To convert ETS values into oxygen utilisation rates (OUR), the currently used factor 0.15 was adopted in samples obtained from 5 to $200 \mathrm{~m}$ (Kenner and Ahmed, 1975). The water layers from 5 to $200 \mathrm{~m}$ are here referred to as euphotic zone, for better compar-

TABLE 1. - References of the sampling areas, cruises, periods sample sizes and water column sampling depths.

\begin{tabular}{lccccl}
\hline Sampling area & Cruise & Period & Sample size & Water column & References \\
\hline Southern Adriatic Sea & AM3 & August 1993 & 32 & $0-1000$ & Azzaro et al., 1998 \\
Southern Adriatic Sea & MATER 6 & August 1998 & 27 & $0-1000$ & Azzaro, 1998 \\
Southern Adriatic Sea & SINAPSI III & Dec. 1998-Jan. 1999 & 10 & $0-1000$ & Zaccone, 1999 \\
Ionian Sea & POEM-LIWEX'95 & March-April 1995 & 14 & $0-3000$ & La Ferla and Azzaro, 2001 \\
Ionian Sea & MATER 6 & August 1998 & 21 & $0-3000$ & Azzaro, 1998 \\
Ionian Sea & SINAPSI III & Dec. 1998-Jan. 1999 & 15 & $0-3000$ & Zaccone, 1999 \\
Levantine Sea & POEM-LIWEX'95 & March-April 1995 & 101 & $0-3000$ & La Ferla and Azzaro, 2001 \\
\hline
\end{tabular}


TABLE 2. - Summary of CDPR ranges determined in the studied surface areas (0-200m).

\begin{tabular}{|c|c|c|c|c|}
\hline Areas & Sample size (n) & $\begin{array}{l}\text { CDPR min - max } \\
\mathrm{mg} \mathrm{C} \mathrm{m}^{-3} \mathrm{~h}^{-1}\end{array}$ & $\begin{array}{c}\text { CDPR } \\
\text { mean value }\end{array}$ & Reference \\
\hline Southern Adriatic Sea & 94 & $0.013-0.083$ & 0.04 & La Ferla et al., 1996 \\
\hline Strait of Otranto & 53 & $0.092-0.122$ & 0.03 & La Ferla et al., 1999 \\
\hline Ionian Sea & 24 & $0.019-0.163$ & 0.05 & La Ferla et al., 1996 \\
\hline Levantine Sea & 19 & $0.010-0.046$ & 0.02 & Azzaro, 1997 \\
\hline
\end{tabular}

ison with other authors (Savenkoff et al., 1993a; Lefèvre et al., 1996; La Ferla et al., 1996).

The ETS values from $200 \mathrm{~m}$ to the bottom were converted into OUR using the conversion factor of 0.43/5 (Packard et al., 1988). The coefficient 0.43 derived from a study of five cultivable marine bacteria species by Christensen et al. (1980); the factor $1 / 5$ is based on an ETS protocol (used in this study) five times more sensitive than the original version (Devol et al., 1976).

Both the euphotic and aphotic OUR were converted to Carbon Dioxide Production Rate (CDPR) in carbon units by applying the following Equation:

$$
\begin{gathered}
\operatorname{CDPR}\left(\mathrm{mg} \mathrm{C} \mathrm{m}^{-3} \mathrm{~h}^{-1}\right)= \\
=\left(\text { OUR ml O} \mathrm{m}^{-3} \mathrm{~h}^{-1} \times 12 / 22.4\right) \times(122 / 172)
\end{gathered}
$$

where 12 is the $\mathrm{C}$ atomic weight, 22.4 the $\mathrm{O}_{2}$ molar volume and 172/122 the Takahashi oxygen/carbon molar ratio (Takahashi et al., 1985). We do not use the O/C molar ratio of 138/106 estimated by Redfield et al. (1963) for a better comparison with the references on respiratory rates in the Mediterranean Sea (Savenkoff et al., 1993a; La Ferla et al., 1996). Euphotic-integrated activity was calculated according to the trapezoidal method whereas aphotic carbon oxidation rate profile was outlined using the power functions of depth according to Packard et al. (1988):

$$
\mathrm{R}_{\mathrm{i}}=\mathrm{A} \mathrm{Z}^{\mathrm{B}},
$$

where $\mathrm{A}$ is the CDPR in $\mathrm{mg} \mathrm{C} \mathrm{m} \mathrm{m}^{-3} \mathrm{~d}^{-1}, \mathrm{Z}$ is the depth below the surface in meters and $\mathrm{B}$ is the exponent of depth. The depth-integrated rate $\left(\int \mathrm{Rdz}\right.$ in $\mathrm{mg} \mathrm{C} \mathrm{m}^{-2}$ $\left.\mathrm{d}^{-1}\right)$ in the water column was calculated within the depth interval between $Z_{1}$ and $Z_{2}$, according to Christensen et al. (1989):

$$
\int \mathrm{Rdz}=\mathrm{A}\left(\mathrm{Z}_{2}{ }^{(\mathrm{B}+1)}-\mathrm{Z}_{1}{ }^{(\mathrm{B}+1)}\right) /(\mathrm{B}+1) .
$$

The coefficients A and B are from Equation (1).

\section{RESULTS}

\section{Photic zone}

In Table 2 a summary of the CDPR ranges and mean values obtained in the upper $200 \mathrm{~m}$ of the Southern Adriatic Sea, Otranto Strait, Ionian Sea and Levantine Sea are reported. The mean values found in the Ionian Sea (CDPR: $0.05 \mathrm{C} \mathrm{m}^{-3} \mathrm{~h}^{-1}$ ) were slightly higher, but comparable to the rates determined in the Southern Adriatic Sea $\left(0.04 \mathrm{mg} \mathrm{C} \mathrm{m}^{-3}\right.$ $\left.\mathrm{h}^{-1}\right)$ and in the Otranto Strait $(0.03 \mathrm{mg} \mathrm{C}$ $\left.\mathrm{m}^{-3} \mathrm{~h}^{-1}\right)$. Lower values occurred in the Levantine Sea $\left(0.02 \mathrm{mg} \mathrm{C} \mathrm{m}^{-3} \mathrm{~h}^{-1}\right)$.

\section{Aphotic zone}

\section{Southern Adriatic Sea}

In Figure 1a, the CDPR values, integrated over the 400-1000 m layer from the Southern Adriatic Sea from 1993 to 1999 are reported. During August
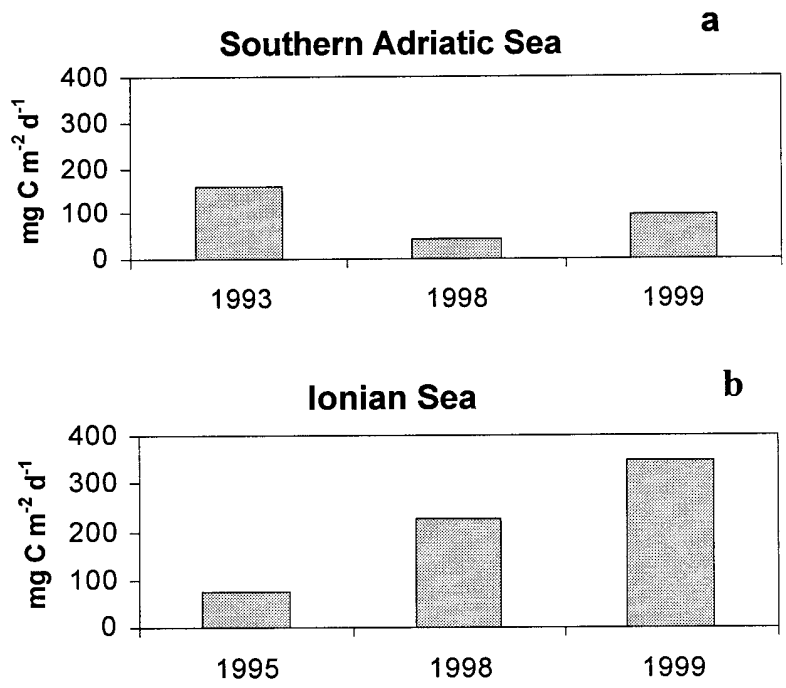

FIG. 1. - Carbon oxidation rates ( $\left.\mathrm{mg} \mathrm{C} \mathrm{m}^{-2} \mathrm{~d}^{-1}\right)$ determined by ETS activity in Southern Adriatic Sea, during 1993 (AM3 cruise), 1998 (MATER 6 cruise), and 1999 (SINAPSI III), and in Ionian Sea, during 1995 (POEM-LIWEX '95), 1998 (MATER 6) and 1999 (SINAPSI III). 


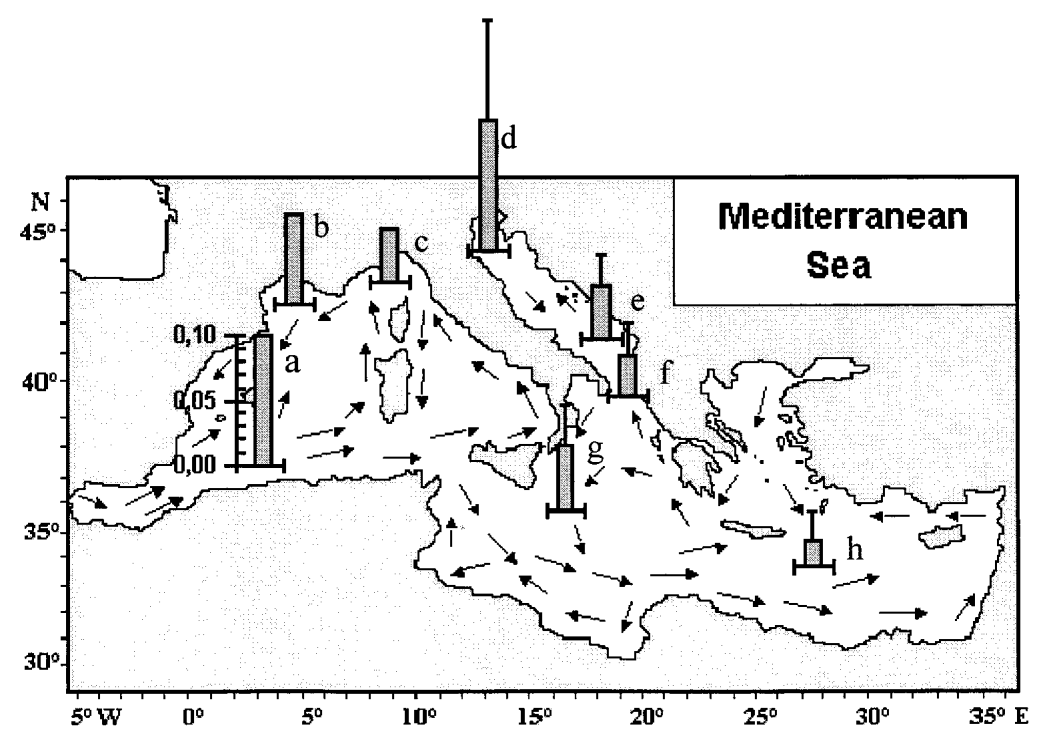

FIG. 2. - Surface circulation pattern and distribution of CDPR mean values $\left(\mathrm{mg} \mathrm{C} \mathrm{m}^{-3} \mathrm{~h}^{-1}\right)$ in the Mediterranean Sea euphotic zones as estimated by various authors (a: Martínez et al., 1990; b: Agustí and Cruzado, 1992; c: Slawyk et al., 1976; d: La Ferla et al., 2001; e and g: La Ferla et al., 1996; f: La Ferla et al., 1999; h: La Ferla and Azzaro, 2001).

1993, Azzaro et al. (1998) found a CDPR of $158 \mathrm{mg}$ $\mathrm{C} \mathrm{m}^{-2} \mathrm{~d}^{-1}$, probably as a consequence of high mixing and homogeneity in the water column, which occurred in winter 1992 (Gacic et al., 1998). In the 1993-1998 period, the convective renewal was generally scanty and as a consequence, the CDPR decreased by a factor three $\left(50 \mathrm{mg} \mathrm{C} \mathrm{m}^{-2} \mathrm{~d}^{-1}\right)$ in August 1998 in the same depth layer. On the contrary, in the following winter 1999, with an increase in the convective processes (Gacic et al., 1998) the CDPR also increased $\left(100 \mathrm{mg} \mathrm{C} \mathrm{m}^{-2} \mathrm{~d}^{-1}\right)$.

\section{Ionian Sea}

Estimates of CDPR were made in February 1995 in St GEO $95\left(35^{\circ} 34.88 \mathrm{~N}, 17^{\circ} 14.99 \mathrm{E}\right)$. The depthintegrated value in the depth layer between 200 and $2500 \mathrm{~m}^{2}$ was $65 \mathrm{mg} \mathrm{C} \mathrm{m}^{-2} \mathrm{~d}^{-1}$ (Fig. 1b). The following data from the deep Ionian Sea -in August 1998 in St I $01\left(38^{\circ} 28.31 \mathrm{~N}, 17^{\circ} 58.35 \mathrm{E}\right)$ - produced rates three times higher $\left(210 \mathrm{mg} \mathrm{C} \mathrm{m}^{-2} \mathrm{~d}^{-1}\right)$. In 1999, the CDPR in the deep waters rose again to $350 \mathrm{mg} \mathrm{C}$ $\mathrm{m}^{-2} \mathrm{~d}^{-1}$ in St. GEO $99\left(38^{\circ} 28.31 \mathrm{~N}, 17^{\circ} 58.35 \mathrm{E}\right)$.

\section{Levantine Sea}

Deep CDPR from 200 to $3000 \mathrm{~m}$ amounted to $177.1 \mathrm{mg} \mathrm{C} \mathrm{m}^{-2} \mathrm{~d}^{-1}$ in the entire Levantine basin. At the depth interval $200-600 \mathrm{~m}$, roughly corresponding to LIW, a CDPR of $52.5 \mathrm{mg} \mathrm{C} \mathrm{m}^{-2} \mathrm{~d}^{-1}$ was found in the whole area. The mean CDPR values were $67.4 \mathrm{mg} \mathrm{C}$ $\mathrm{m}^{-2} \mathrm{~d}^{-1}$ for the depth range between 600 and $1600 \mathrm{~m}$ and $57.2 \mathrm{mg} \mathrm{C} \mathrm{m}^{-2} \mathrm{~d}^{-1}$ for the deeper layer (depth range 1600-3000 m) occupied by CDW (Fig. 3).

\section{DISCUSSION AND CONCLUSION}

Figure 2 reports a summary of the CDPR mean values, extrapolated from data determined in different Mediterranean photic zones $(0-200 \mathrm{~m})$ by authors referenced in the legend. It also shows the surface water circulation pattern. Higher values were found in the Western Mediterranean (a: mean value, $0.10 \mathrm{mg} \mathrm{C} \mathrm{m}^{-3} \mathrm{~h}^{-1}$ ), in the Gulf of Lyons (b: $0.07 \mathrm{mg} \mathrm{C} \mathrm{m}^{-3} \mathrm{~h}^{-1}$ ) and in the Northern Adriatic Sea (d: $0.09 \mathrm{mg} \mathrm{C} \mathrm{m}^{-3} \mathrm{~h}^{-1}$ ). Intermediate values were found in the Ionian Sea (g: $0.05 \mathrm{mg} \mathrm{C} \mathrm{m}^{-3} \mathrm{~h}^{-1}$ ), in the Southern Adriatic and along the French Mediterranean Coast (e-c: $0.04 \mathrm{mg} \mathrm{C} \mathrm{m}^{-3} \mathrm{~h}^{-1}$ ) as well as in the Otranto Strait (f: $0.03 \mathrm{mg} \mathrm{C} \mathrm{m}^{-3} \mathrm{~h}^{-1}$ ). A lower CDPR was estimated for the Levantine Sea (h: 0.02

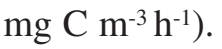

Due to the high net evaporation, the characteristics of the Atlantic surface waters (ASW) changed along their flow through the Gibraltar Strait to the east (Hopkins, 1978). Biomass, production, nutrients, and remote sensing activities detected by satellite sensors (Dowidar, 1984; Antoine et al., 1995; Magazzù and Decembrini, 1995) gradually decrease from west to east, in the surface layers. Another source of high activity 
originates in the riverine outflows in the Northern Adriatic and in the Gulf of Lyons. As a consequence, the oxidative processes in the surface Mediterranean waters decrease from West to East and from North to South associated with the Mediterranean circulation pattern (Martínez et al., 1990; La Ferla et al., 1996, 1999) and in agreement with the conceptual model proposed by Crise and Crispi (1998) on the coupling of physical forcing and biological processes.

The overall picture until 1995 derived from the volume specific CDPR for the entire Mediterranean Sea is schematically illustrated in Figure 3. In the euphotic zone between 0 and $200 \mathrm{~m}$, later on called ASW (Atlantic Surface Water) from its site of origin, the water drifts from the Atlantic Ocean toward the Levantine basin. The oxidative rates decrease as discussed before. On the contrary, a gradual decrease in oxidative processes in the LIW layer, from the Levantine basin westward through the Ionian Sea and Western Basin was observed. Savenkoff et al. (1993a) stated that LIW waters of Mediterranean origin expanded out through the Straits of Gibraltar, in the north-east Atlantic. He depicts this layer as a salty tongue, plunging to depths where oxidative processes increased (33.7 $\mathrm{mg} \mathrm{C} \mathrm{m}{ }^{-2} \mathrm{~d}^{-1}$ in the depth range between 600 and $1600 \mathrm{~m}$ ). The authors explained this higher activity by the occurrence of the anticyclonic rotation of
Meddy Nicole, which would attract or entrap sedimenting particulate matter and thus significantly raise the oxidation rates.

Concerning the deep-waters (Fig. 3), these originated in the N-W Mediterranean Basin (Gulf of Lyons) and in the Southern Adriatic. In the N-W Mediterranean Sea, the deep-water oxidation rate (Lefèvre et al., 1996) decreased with the spreading of the water mass from the origin site towards the entire Western basin (Christensen et al., 1989). Within the Eastern Basin, the EMDW formation site is located in the Southern Adriatic Sea, from where the oxidation rate estimated by Azzaro et al. (1998) decreased while the waters spread towards the Ionian Basin (La Ferla and Azzaro, 2001). Continuing towards the Levantine sector of the Mediterranean basin, the EMDW, spreading in the upper $1600 \mathrm{~m}$ depth, showed lower oxidation rates. The input from the new CDW, that replaced the pre-existing deepest water mass below $1600 \mathrm{~m}$ depth, sustained an oxidation rate of $57.2 \mathrm{mg} \mathrm{C} \mathrm{m}^{-2} \mathrm{~d}^{-1}$.

With the aim of showing that the Mediterranean Sea could be considered suitable as a study basin for oceanic processes, Azzaro (1997) proposed the following power function (CDPR - mg C m $\mathrm{m}^{-3} \mathrm{~d}^{-1}=$ $2.467 \mathrm{z}^{-0,631}$ ) for extrapolating the vertical CDPR profile for the whole Mediterranean Sea from $100 \mathrm{~m}$ to the bottom. Christensen et al. (1989) already used this kind of representation for the CDPR in the

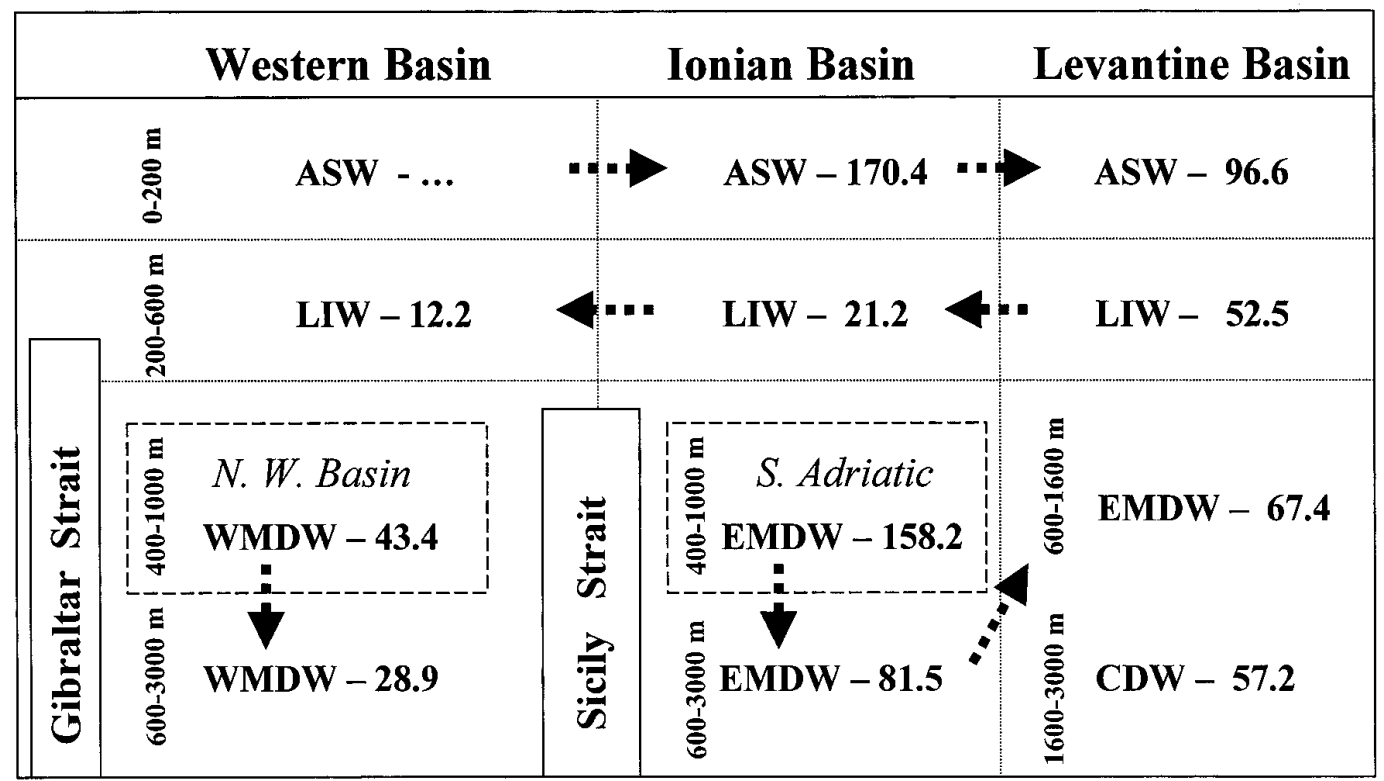

FIG. 3. - Schematic diagram summarising the coupling between CDPR $\left(\mathrm{mg} \mathrm{C} \mathrm{m}^{-2} \mathrm{~d}^{-1}\right)$ and the main Mediterranean water masses. Arrows indicate the direction of the water mass flux between boxes. The main body of the Mediterranean Sea is divided into the Western, Ionian and Levantine basins. Two additional sub-systems, in the dashed line boxes, represent the deep (NW Mediterranean Basin and Southern Adriatic) water formation areas. Data are calculated from: Lefèvre et al. (1996) and Christensen et al. (1989) for Western Basin water mass; Azzaro et al. (1998) for Southern Adriatic; La Ferla et al. (1996) and La Ferla and Azzaro (2001) for Ionian and Levantine water mass. Modified from La Ferla and Azzaro (2001). 


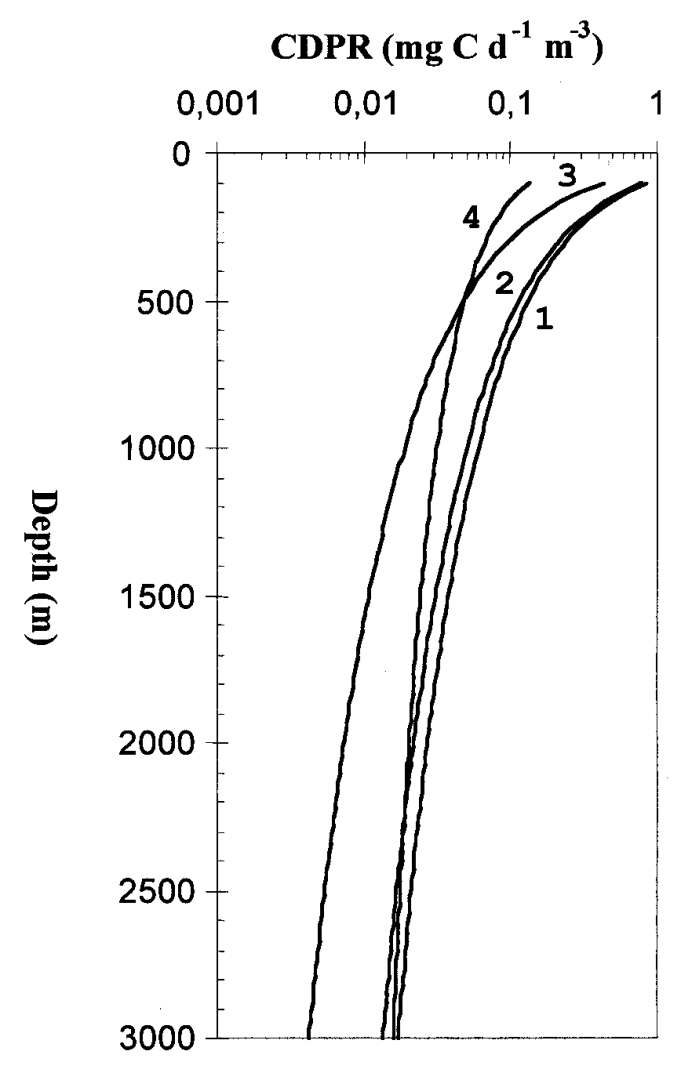

\section{Pacific Ocean \\ 3 Atlantic Ocean \\ 2 Indian Ocean \\ 4 Mediterranean Sea}

FIG. 4. - Comparison of best-fit functions representing the depth dependence of CDPR in the Mediterranean Sea by Azzaro (1997), Atlantic and Pacific Oceans by Packard et al. (1988) and Indian Ocean by Naqvi et al. (1996).

Western Mediterranean Sea. Such integration of the data does not take into account the discontinuity of the respiratory rates along the water column due to the different microbial population structure with depth, such as those observed by Savenkoff et al. (1993b) for the Liguro-Provençal front (Western Mediterranean Sea). Furthermore, it does not account for the variability in the oxidative processes in the different sub-basins as previously described.

TABLE 3. - Ratios calculated between depth-integrated deep CDPR values (from 1500 to $2500 \mathrm{~m}$ ) and depth-integrated shallow CDPR values (from 200 to $1200 \mathrm{~m}$ ) in sites of the Mediterranean Sea, Atlantic, Pacific and Indian Oceans.

\begin{tabular}{lcl}
\hline Area & Rdz ratio (\%) & References \\
\hline Mediterranean Sea & 46.6 & Azzaro, 1997 \\
Atlantic Ocean & 14.9 & Packard et al., 1988 \\
Pacific Ocean & 21.1 & Packard et al., 1988 \\
Indian Ocean & 24.8 & Naqvi et al., 1996 \\
\hline
\end{tabular}

However, it well underlines the peculiarity of the deep Mediterranean waters with respect to other oceanic deep waters. In Figure 4, we compare the Mediterranean profile to those from Pacific, Atlantic and Indian oceans (Packard et al., 1988; Naqvi et $a l .$, 1996). The decrease with depth of the Mediterranean CDPR is exponential. However it is less pronounced than for Pacific and Indian waters since its exponent is less negative, as already computed by Christensen et al. (1989) for the Western Mediterranean Sea. Such evidence underlines the considerable importance of remineralization in the Mediterranean deep layers with respect to similar oceanic depths. Since the Mediterranean surface water is known for its oligotrophy, this pattern seems mainly caused by the important advective processes occurring in the Mediterranean rather than by export production from the upper layers. In Table 3, the ratios calculated between depth-integrated deep CDPR values (from 1500 to $2500 \mathrm{~m}$ ) and shallow CDPR values (from 200 to $1200 \mathrm{~m}$ ) in the Mediterranean Sea with respect to the oceans (before 1995) are reported. They clearly mark the peculiarity of this basin with regard to the deep remineralization processes as already referred by La Ferla et al. (in press). Such evidence is explained partially by the high temperatures of the Mediterranean deep water $\left(\sim 13^{\circ} \mathrm{C}\right)$, which accelerates microbial metabolism, and partially also by the availability of organic carbon suitable for remineralisation in the deep biota (Seritti et al., in press).

Calculating the carbon budget in the Eastern Mediterranean Sea, we compare the remineralization patterns obtained by various authors (Fig. 5). Before 1987, Bethoux (1989) estimated a remineralization rate close to $32.9 \mathrm{mg} \mathrm{C} \mathrm{m}^{-2} \mathrm{~d}^{-1}$ with a $3 \%$ increase per year. This trend was revised by Roether and Well (2001) who estimated higher rates in 1987. Our estimate in 1995 (74.5 $\left.\mathrm{mg} \mathrm{C} \mathrm{m}^{-2} \mathrm{~d}^{-1}\right)$ was still higher than previous ones. Moreover, considerably higher remineralization occurred after EMT events: 226.7 and $349.9 \mathrm{mg} \mathrm{C} \mathrm{m}^{-2} \mathrm{~d}^{-1}$ in 1998 and 1999, respectively. These findings highlight the accelerated remineralization rates in the Mediterranean depth. As a compensation, the intrusion of young waters with higher values of preformed oxygen negates the large spike in respiration (Klein et al., 1999) so that the predicted anoxia is delayed.

In conclusion, assuming that the Mediterranean Sea has an area of $2.52 \times 10^{12} \mathrm{~m}^{2}$ and assuming that the CDPR value (determined until 1995), extrapolated by integrating data from 200 to $1500 \mathrm{~m}$ (since the 


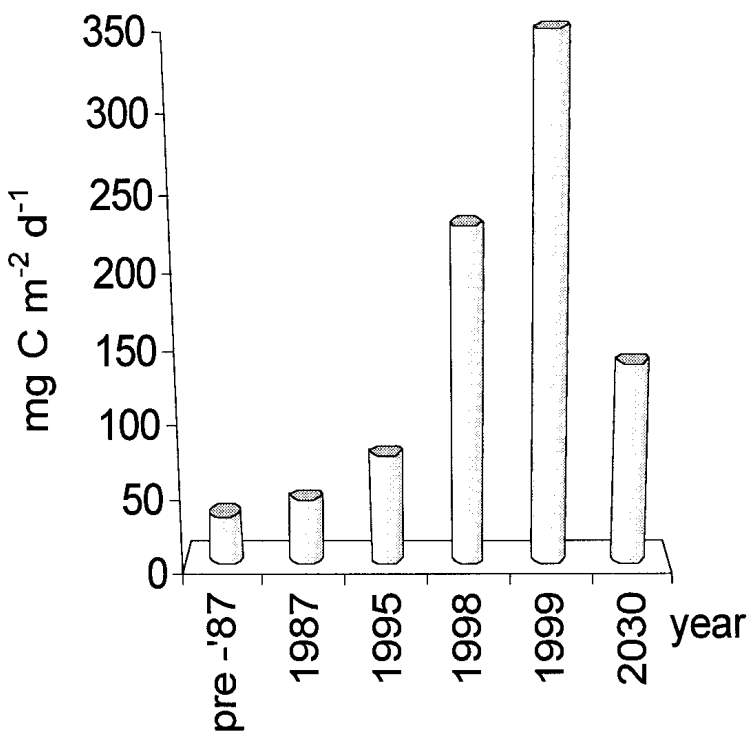

FIG. 5. - Remineralization rates determined in the Eastern Mediterranean Sea from prior to 1987 , from1987 to 1999 data and a projection to 2030. Pre- 87 and 2030 data by Bethoux (1989); 1987 by Roether and Well (2001); 1995 by La Ferla and Azzaro (2001); 1998 by Azzaro (1998); 1999 by Zaccone (1998).

latter is the mean depth of the Mediterranean basin) is representative of the entire basin, a remineralization rate of $47.9 \times 10^{12} \mathrm{~g} \mathrm{C}$ yearly is estimated. This is higher than the previous calculation by Bethoux (1989), of $29.8 \times 10^{12} \mathrm{~g} \mathrm{C} \mathrm{y}^{-1}$, and represents the $0.2 \%$ of the global new production calculated from other ETS data (Packard et al., 1988). However, the temporary EMT event and the yet-unknown evolution of the deep water renewal, just occurring in the Mediterranean Sea, do not permit closure of the carbon budget to date.

\section{ACKNOWLEDGEMENTS}

The study was funded by SINAPSI project.

\section{REFERENCES}

Agustì, S. and A. Cruzado. - 1992. Relationship between light absorption by pelagic particles and microplankton metabolic activity in the Gulf of Lions. Mar. Ecol. Progr. Ser., 85: 283-287.

Ahmed, S.I., R.A. Kenner and F.D. King. - 1976. Preservation of enzymatic activity in marine plankton by low-temperature freezing. Mar. Chem., 4: 133-139.

Antoine, D., A. Morel, and J.-M. André. - 1995. Algal pigment distribution and primary production in the eastern Mediterranean as derived from coastal zone color scanner observations, $J$. Geoph. Res., 100 (C8): 16,193-16,209.

Azzaro, M. - 1997. Attività respiratoria (ETSa) e biomassa microbica (ATP) nel Mediterraneo Orientale. Thesis, Natural Science Univ., Messina, Italy, unpublished, pp. 1-68.

Azzaro, M. - 1998 . MATER: MAI 6-98 Cruise Report, August $18^{\text {th }}$ $-31^{\text {st }}, 1998$.

Azzaro, M., G. Chiodo and E. Crisafi. - 1998. Utilizzo del saggio
ETSa per lo studio dei tassi respiratori del microplancton nella zona afotica. In: M. Piccazzo (ed.), Proceedings XII ${ }^{\circ}$ A.I.O.L. Congress, Genova, II, pp. 323-329.

Bethoux, J.P. - 1989. Oxygen consumption, new production, vertical advection and environmental evolution in the Mediterranean Sea. Deep-Sea Res., 36(5): 769-781.

Christensen, J.P., Owens, T.G., Devol, A.H. and T.T. Packard. 1980, Respiration and physiological state in marine bacteria. Mar. Biol., 55: 267-276.

Christensen, J.P., Packard, T.T., Dortch, F.Q., Minas, H.J., Gascard, J.C., C. Richez and P.C. Garfield. - 1989. Carbon oxidation in the deep Mediterranean Sea: evidence for dissolved organic carbon source. Glob. Biogeochem. Cycles, 3: 315-335.

Crise, A. and G. Crispi. - 1998. The effect of physical forcings on the nutrients gradients in the Mediterranean Sea: a numerical approach. Rapp. Comm. Int. Mer Méd., 35: 112-113.

Devol, A.H., T.T. Packard and O. Holm Hansen. - 1976. Respiratory electron transport activity and adenosine triphosphate in the oxygen minimum of the eastern tropical North Pacific. Deep-Sea Res., 23: 963-973.

Dowidar, N.M. - 1984. Phytoplankton biomass and primary productivity of the south-eastern Mediterranean. Deep-Sea Res., 31: 983-1000.

Eppley, R.W., and B.J. Peterson. - 1979. Particulate organic matter flux and planktonic new production in the deep ocean. Nature, 282: 677-680.

Gacic, M., Kovacevic, V., Cardin V., G. Civitarese and C. Fragiacomo. - 1998. Interannual air-sea heat flux variability, deep convection and biochemical properties in the Southern Adriatic. In: $3^{\text {rd }}$ MTP-II Mater workshop proceedings, 56-58 Rhodes, Greece.

Hopkins, T.S. - 1978. Physical Processes in the Mediterranean Basins. In: B. Kjerfve (ed.), Estuarine Transport Processes, pp. 269-310, Univ of South Carolina Press.

Kenner, R.A. and S.J. Ahmed. - 1975. Measurement of electron transport activities in marine phytoplankton. Mar. Biol., 33: 119-128.

Klein, B., W., Roether, B.B Manca, D., Bregant, V. Beitzel., V. Kovacevic and A. Lucchetta. 1999. The large deep water transient in the Eastern Mediterranean. Deep-Sea Res. Part I, 46: 371-414.

Klein, B., Roether, W., Civitarese, G., Gacic, M., B.B. Manca and M. Ribera d'Alcalà. - 2000. Is the Adriatic returning to dominate the production of Eastern Mediterranean deep-water? Geoph. Res. Letters, 27(20): 3377-3380.

La Ferla, R., M. Azzaro and G. Chiodo. - 1996. Microbial respiratory activity in the euphotic zone of the Mediterranean Sea. Microbiologica, 19: 243-250.

La Ferla, R., M. Azzaro and G. Chiodo. - 1999. Microplankton respiratory activity and $\mathrm{CO}_{2}$ production rates in the Otranto Strait (Mediterranean Sea). Aquat. Ecol., 33: 157-165.

La Ferla R., Zaccone R., Caruso G., Azzaro M. - 2001. Enzymatic activities and carbon flux through the microbial compartment in the Adriatic Sea. In: F.M. Faranda, L. Guglielmo and G. Spezie (eds.), Mediterranean Ecosystems: Structures and Processes, pp. 485-493. Springer-Verlag, Italia.

La Ferla, R. and M. Azzaro. - 2001. Microbial respiration in the Levantine Sea: evolution of the oxidative processes in relation to the main Mediterranean water masses. Deep-Sea Res. Part I: $1-13$.

La Ferla R., Azzaro M., Civitarese G. and Ribera D'Alcalà M. - (in press). Distribution patterns of carbon oxidation in the Eastern Mediterranean Sea: evidence of changes in remineralization processes. J. Geoph. Res. Special issue.

Lascaratos, A., Roether, W., K. Nittis and B. Klein. - 1999. Recent changes in deep water formation and spreading in the Eastern Mediterranean Sea: a review. Progr. Oceanogr., 44(1-3): 5-36.

Lefèvre, D., M. Denis, C.E. Lambert and J.C. Miquel. - 1996. Is DOC the main source of organic matter remineralization in the ocean water column? J. Mar. Syst., 7: 281-291.

Longhurst, A.R. and W.B. Harrison. 1989 - The biological pump: profiles of plankton production and consumption in the upper ocean. Progr. Oceanogr., 22: 47-122.

Magazzù, G. and F. Decembrini. - 1995. Primary production, biomass and abundance of phototrophic picoplankton in the Mediterranean Sea: a review. Aquat. Microb. Ecol., 9: 97-104.

Martínez, R., R.A. Arnone and Z. Velásquez. - 1990. Chlorophyll $a$ and respiratory activity in microplankton from surface waters 
of the Western Mediterranean. J. Geoph. Res., 95: 1615-1622.

Naqvi, S.W.A., Shailaja, M.S., M. Dileep Kumar and R. Sen Gupta. - 1996. Respiration rates in subsurface waters of the northern Indian Ocean: evidence for low decomposition rates of organic matter within the water column in the Bay of Bengal. Deep-Sea Res. Part II, 43: 73-81.

Packard, T.T. - 1971. The measurement of respiratory electron transport activity in marine phytoplankton. J. Mar. Res., 29: 235-244

Packard, T.T., A.H. Devol and F.D. King. - 1975. The effect of temperature on the respiratory electron transport system in marine plankton. Deep-Sea Res., 22: 237-249.

Packard, T.T. and P.J. Le B. Williams. - 1981. Rates of respiratory oxygen consumption and electron transport in surface sea water from the Northwest Atlantic. Oceanol. Acta, 4: 351-358.

Packard, T.T., M. Denis, M. Rodier and P. Garfield. - 1988. Deepocean metabolic $\mathrm{CO}_{2}$ production: calculations from ETS activity. Deep-Sea Res., 35: 371-382.

Psarra, S., A. Tselepides, L. Ignatiades. - 2000. Primary productivity in the oligotrophic Cretan Sea (NE Mediterranean): seasonal and interannual variability. Progr. Oceanogr., 46: 187-204.

Redfield, A.C., B.H. Ketchum, F.A. Richards. - 1963. The influnce of organisms on the composition of seawater. In: M.N. Hill (ed.), The Sea, pp: 26-77. Interscience, New York.

Roether, W., B.B. Manca, B. Klein, D. Bregant, D. Georgopoulos, V. Beitzel, V. Kovacevic and A. Luchetta. - 1996. Recent changes in the Eastern Mediterranean deep water. Science, 271: 333-335.

Roether, W. and R. Well. - 2001. Oxygen consumption in the Eastern Mediterranean. Deep-Sea Res. Part I, 48: 1535-1551.

Savenkoff, C., Lefèvre, D., M. Denis and C.E. Lambert. - 1993a. How do microbial communities keep living in the Mediterranean outflow within northeast Atlantic Intermediate Waters? Deep-Sea Res. Part II, 40(1-2): 627-641.
Savenkoff, C., L. Prieur, J.P. Reys, D. Lefèvre, S. Dallot and M. Denis. 1993b. Deep microbial communities evidenced in the Liguro-Provençal front by their ETS activity. Deep-Sea Res. Part I, 40: 709-725.

Seritti, A., C. Santinelli, B.B. Manca, E. Murru, A. Boldrin, L. Nannicini. - (in press). Dissolved Organic Carbon (DOC) as potential signature of water column processes: the Ionian Sea feature in 1999. J. Geoph. Res. Special issue.

Slawyk, G., H.J. Minas and T.T. Packard - 1976 A further investigation on the primary productivity in the divergence zone near the French Mediterranean coast. Int. Rev. ge.s Hydrobiol., 61: 373-381.

Souvemerouglou, E., E. Krasakopoulou and A. Pavlidou. - 1999. Temporal variability in oxygen and nutrient concentrations in the Southern Aegean Sea and the Straits of the Cretan Arc. Progr. Oceanogr., 44: 537-600.

Sundquist E.T. - 1985. In: E.T. Sundquist and W.S. Broeker, (eds.), The carbon cycle and atmospheric $\mathrm{CO}_{2}$ : natural variations archean to present. Geophysical Monograph, 32, pp. 5-59.

Takahashi, T., W.S. Broecker and S. Langer. - 1985. Redfield ratio based on chemical data from isopycnal surfaces. J. Geoph. Res., 90: 6907-6924.

Theocharis, A. and A. Lascaratos. - 2000. Possible causes, origin, evolution and some consequences of the Eastern Mediterranean Transient during the period 1987-1999. In: CIESM Workshop Series, 10.

Tselepides, A., V. Zervakis, T. Polychronaki, R. Danovaro and G. Chronis. - 2000. Distribution of nutrients and particulate organic matter in relation to the prevailing hydrographic features of the Cretan Sea (NE Mediterranean). Progr. Oceanogr., 46: 113-142.

Zaccone, R. - 1999. Marine Ecosystem/SINAPSI project, Yearly Reports. 